\title{
PEMBELAJARAN FISIKA MELALUI KONSTRUKTIVISME MENGGUNAKAN METODE INKUIRI TERBIMBING DAN INKUIRI BEBAS TERMODIFIKASI DITINJAU DARI MOTIVASI BERPRESTASI DAN SIKAPILMIAH
}

\author{
Arif Handaka ${ }^{1}$, Sukarmin ${ }^{2}$, dan Widha Sunarno ${ }^{3}$ \\ ${ }^{1}$ Program Studi Magister Pendidikan Sains FKIP Universitas Sebelas Maret \\ Surakarta, 57126, Indonesia \\ arief_handaka@yahoo.com \\ ${ }^{2}$ Program Studi Magister Pendidikan Sains FKIP Universitas Sebelas Maret \\ Surakarta, 57126, Indonesia \\ sukarmin67@staff.uns.ac.id \\ ${ }^{3}$ Program Studi Magister Pendidikan Sains FKIP Universitas Sebelas Maret \\ Surakarta, 57126, Indonesia \\ widhasunarno@staff.uns.ac.id
}

\begin{abstract}
Abstrak
Penelitian ini bertujuan untuk mengetahui pengaruh pembelajaran konstruktivisme menggunakan metode inkuiri bebas termodifikasi dan inkuiri terbimbing terhadap prestasi belajar (pengetahuan, sikap, dan keterampilan) peserta didik ditinjau dari sikap ilmiah dan motivasi berprestasi peserta didik. Penelitian ini merupakan penelitian kuasi eksperimen yang dilakukan pada kelas XI di SMA Batik 2 Surakarta semester gasal tahun pelajaran 2015/2016. Penelitian melibatkan pembelajaran konstruktivisme dengan metode inkuiri bebas termodifikasi dan inkuiri terbimbing sebagai variabel bebas, sikap ilmiah dan motivasi berprestasi sebagai variabel moderator, serta prestasi belajar (pengetahuan, sikap, dan keterampilan) peserta didik sebagai variabel terikat. Pengumpulan data prestasi belajar (pengetahuan) dalam bentuk tes tertulis, sedangkan data prestasi belajar (sikap dan keterampilan) dalam bentuk pengamatan. Teknik analisis data menggunakan ANAVA 3 jalan dengan rancangan faktorial $2 \times 2 \times 2$. Hasil penelitian menunjukkan bahwa, (1) ada perbedaan pengaruh pendekatan konstruktivisme menggunakan metode inkuiri bebas termodifikasi dan metode inkuiri terbimbing terhadap nilai pengetahuan, sikap dan keterampilan, (2) ada perbedaan pengaruh antara sikap ilmiah tinggi dan rendah terhadap nilai pengethuan, sikap dan keterampilan, (3) ada perbedaan pengaruh antara motivasi berprestasi tinggi dan rendah terhadap nilai pengetahuan, sikap dan keterampilan, (4) tidak ada interaksi pengaruh antara pendekatan konstruktivisme menggunakan metode inkuiri bebas termodifikasi dan metode inkuiri terbimbing dengan sikap ilmiah terhadap nilai pengetahuan, sikap dan keterampilan, (5) tidak ada interaksi pengaruh antara pembelajaran dengan pendekatan konstruktivisme menggunakan metode inkuiri bebas termodifikasi dan metode inkuiri terbimbing dengan motivasi berprestasi terhadap prestasi pengetahuan siswa, namun memberikan pengaruh yang signifikan terhadap nilai sikap dan keterampilan, (6) tidak ada interaksi pengaruh antara sikap ilmiah dengan motivasi berprestasi terhadap prestasi pengetahuan dan keterampilan namun memberikan pengaruh yang signifikan terhadap sikap siswa, dan (7) tidak ada interaksi pengaruh antara pembelajaran dengan pendekatan konstruktivisme menggunakan metode inkuiri bebas termodifikasi dan ikuiri terbimbing, sikap ilmiah, dan motivasi berprestasi terhadap prestasi aspek pengetahuan, sikap, dan keterampilan.
\end{abstract}

Kata kunci: Konstruktivisme, Inkuiri Bebas Termodifikasi, Inkuiri Terbimbing, Motivasi Berprestasi, Sikap Ilmiah 


\section{Pendahuluan}

Nilai fisika siswa SMA BATIK 2 Surakarta belum optimal, hal tersebut disebabkan oleh beberapa hal yaitu: (1) siswa kesulitan menghapalkan konsep yang sangat banyak, (2) terlalu banyak rumus yang harus dihapalkan, (3) variasi metode pembelajaran yang digunakan masih sedikit, didominasi oleh metode konvensional seperti ceramah. Walaupun pendapat tersebut bukan satu-satunya penyebab rendahnya nilai fisika, tetapi pendapat tersebut layak dipertimbangkan untuk mengatasi masalah tersebut. Masalah persepsi bahwa pelajaran fisika terasa sulit telah sering ditemui di sekolah lain. Siswa menganggap fisika merupakan pelajaran menghapal. Hal ini tentunya bertentangan dengan hakikat fisika yaitu terdiri dari proses, produk, dan sikap.

Beberapa guru mengakui bahwa pembelajaran fisika masih teacher centered, bukan student centered. Metode pembelajaran yang digunakan masih didominasi oleh ceramah, tanya jawab maupun diskusi konvensional. Hal ini mengakibatkan pembelajaran lebih menekankan pada pemindahan informasi dari guru kepada siswa sehingga siswa harus menghapal konsep ataupun rumus tersebut. Aktivitas berpikir ilmiah siswa menjadi sangat terbatas.

Beberapa guru juga telah berusaha menggunakan metode pembelajaran yang bervariasi, tetapi belum menunjukkan hasil yang maksimal. Hal ini disebabkan pemilihan metode pembelajaran sering tidak sesuai dengan karakteristik materi yang diajarkannya. Guru sering mengabaikan hakikat fisika sebagai produk, psroses, dan sikap dan cara mengajarkan setiap bagiannya. Materi yang membutuhkan penyelidikan di laboratorium sering diajarkan dengan menggunakan metode diskusi di kelas. Hal ini tentunya semakin membingungkan siswa, sehingga pemahaman siswa menjadi tidak maksimal.

$\begin{array}{rcr}\text { Salah } & \text { satu } & \text { pendekatan } \\ \text { pembelajaran } & \text { yang } & \text { sesuai }\end{array}$ pembelajaran fisika adalah konstruktivisme. Pembelajaran dengan pendekatan konstruktivisme menghendaki pembentukan pengetahuan terjadi di dalam pikiran siswa sendiri. Menurut Van Glassersfeld dalam Suparno (2007:8) "Filsafat konstruktivisme adalah filsafat yang mempelajari hakikat pengetahuan dan bagaimana pengetahuan itu terjadi". Siswa melakukan pembelajarannya sendiri dengan bimbingan guru. Siswa membangun konsep-konsep yang dimilikinya menggunakan pengalaman pembelajaran yang dialaminya. Selanjutnya siswa melakukan asimilasi dan akomodasi terhadap konsep-konsep yang dimilikinya

Konstruktivisme memiliki berbagai metode dalam pelaksanaannya. Dua metode yang memiliki ciri konstruktivisme yaitu pembuktian dan penemuan (inkuiri). Kedua metode ini menitikberatkan pada keterlibatan langsung siswa dalam pembentukan konsep oleh siswa. Tugas guru sebagai fasilitator menyediakan suasana pembelajaran yang memungkinkan pembentukan konsep terjadi tanpa adanya rasa keterpaksaan pada diri siswa.

Penelitian ini menggunakan metode inkuiri. Hal ini dilakukan karena siswa di SMA Batik 2 Surakarta sudah memiliki pengalaman jika diterapkan pembelajaran dengan model inkuiri. Metode tersebut merupakan bagian inti dari kegiatan pembelajaran berbasis kontekstual.

Pembelajaran menggunakan metode inkuiri dirancang merujuk pada kegiatan menemukan apapun materi yang diajarkanya. Dalam penelitian terdapat dua metode inkuiri yang dibandingkan pengaruhnya terhadap prestasi belajar. Dua metode tersebut yaitu inkuiri terbimbing dan inkuiri bebas termodifikasi. Inkuiri terbimbing merupakan inkuiri dengan volume bimbingan guru yang paling luas. Guru memberikan suatu masalah berdasarkan fenomena riil yang sering dijumpai oleh siswa. Guru menuntun penyusunan hipotesis hingga penarikan kesimpulan dengan menggunakan bantuan pertanyaan. Akan tetapi keterlibatan siswa 
tetap menjadi hal yang utama di dalam inkuiri ini. Untuk pelaksanaan metode inkuiri bebas termodifikasi dengan cara guru memberikan masalah yang harus dipecahkan oleh siswa. Selanjutnya siswa bekerja untuk mendapatkan konsep yang diharapkan oleh pembelajaran. Selama proses inkuiri guru memberikan bimbingan agar proses penyelidikan tidak menyimpang dari rencana pembelajaran. Bimbingan yang diberikan oleh guru berupa pertanyaan yang bersifat mengarahkan siswa untuk berpikir dan termotivasi untuk belajar. Pemberian perlakuan tersebut diterapkan pada kelas yang berbeda sehingga dapat dibandingkan pengaruh penggunaan metode pembelajaran terhadap prestasi belajar siswa.

Keberhasilan pembelajaran fisika dipengaruhi oleh berbagai faktor salah satunya adalah motivasi. Dalam proses belajar motivasi sangat diperlukan sebab sesorang yang tidak mempunyai motivasi dalam belajar, tidak akan mungkin melakukan aktifitas belajar sehingga prestasi belajar siswa juga akan baik. Selain motivasi berprestasi keberhasilan pembelajaran fisika juga ditentukan oleh sikap ilmiah. Sikap ilmiah siswa dapat ditumbuh kembangkan melalui kegiatan percobaan dalam proses pembelajaran. Adnyani dkk (2013) menyatakan bahwa siswa belajar sambil melakukan sendiri dalam menemukan konsep yang dipelajari, siswa akan memperoleh pengalaman lebih bermakna dan lebih kuat melekat dalam pikiran siswa.

Materi Impuls, Momentum, dan Tumbukan sangat erat hubungannya dengan kehidupan sehari-hari siswa. Namun dalam proses pembelajaran siswa mengalami kesulitan mengaitkan antara konsep dengan kehidpan sehari-hari yang dialami. Oleh karena itu penggunaan inkuiri diharapkan siswa dapat menemukan sendiri peristiwa yang berkaitan dengan materi. Melalui pembelajaran konstruktivisme dengan inkuiri terbimbing dan inkuiri bebas keterlibatan siswa dapat dioptimalkan. Siswa melakukan proses penyelidikan dan pembuktian sendiri. Akhirnya siswa diharapkan memahami konsep Impuls, Momentum, dan Tumbukan yang sebenarnya.

\section{Metode Penelitian}

Penelitian ini dilakukan di XI MIA 1 dan XI MIA 2 SMA BATIK 2 Surakarta pada semester I Tahun Pelajaran 2015/2016. Pelaksanaan penelitian ini dilakukan secara bertahap dan sesuai dengan tahapan-tahapan penelitian yang telah disusun. Adapun tahap-tahap pelaksanaannya yaitu 1) Tahap persiapan, meliputi: pengajuan judul tesis, permohonan pembimbing, pembuatan proposal, pembuatan instrumen, perijinan penelitian kepala lembaga terkait, konsultasi instrumen penelitian, dan validasi instrumen, 2) Tahap penelitian, yaitu semua kegiatan yang dilaksanakan di tempat penelitian, meliputi: uji instrumen penelitian dan pengambilan data yang disesuaikan dengan alokasi waktu penyampaian materi impuls, momentum, dan tumbukan. 3) Tahap penyelesaian, meliputi: analisis data dan penyusunan laporan tesis.

Teknik pengambilan data dilakukan dengan pemberian tes, observasi, angket dan dokumentasi. Data hasil belajar siswa diperoleh dari hasil tes pengetahuan. Pada angket motivasi berprestasi dan sikap ilmiah diperoleh setelah proses pembelajaran, bertujuan untuk mengetahui motivasi berprestasi dan sikap ilmiah yang dimiliki siswa. Metode observasi dilakukan untuk mengambil data hasil belajar sikap dan keterampilan siswa. Metode dokumentasi dilakukan sebelum penelitian dan selama penelitian.

Uji validitas pada tes hasil belajar pengetahuan dilakukan untuk mengetahui apakah alat evaluasi itu layak digunakan. Hasil soal tes pengetahuan uji coba kemudian dihitung validitas, reliabilitas, daya beda soal, indeks kesukaran, validitas dan reliabilitas. Angket motivasi berprestasi dan sikap ilmiah divalidasi oleh ahli 
instrumen penelitian. Teknik analisis data pada penelitian ini terdiri dari uji prasyarat dan uji hipotesis. Pada uji prasyarat meliputi uji normalitas dan uji homogenitas. Pada uji hipotesis data penelitian menggunakan uji Anava 2x2x2 .

\section{Hasil Penelitian dan Pembahasan}

Berdasarkan hasil uji normalitas dan homogenitas didapatkan kesimpulan bahwa data yang diperoleh terdistribusi normal dan varian datanya homogen. Karena uji normalitas dan homogenitas telah dipenuhi kemudian dilakukan uji anava. Hasil uji hipotesis seperti pada Tabel 1 dibawah ini:

\begin{tabular}{lccc}
\multicolumn{4}{c}{ Tabel 1. Hasil Uji Anava } \\
\hline \multirow{2}{*}{ Variabel } & $\begin{array}{c}\text { Pengetah } \\
\text { uan }\end{array}$ & Sikap & $\begin{array}{c}\text { Keteramp } \\
\text { ilan }\end{array}$ \\
\cline { 2 - 4 } & $\begin{array}{l}P \text {-value } \\
\text { Metode }\end{array}$ & P-value & P-value \\
\hline Sikap & 0,011 & 0,007 & 0,001 \\
\hline Motivasi & 0,000 & 0,000 & 0,000 \\
\hline Metode-Sikap & 0,006 & 0,041 & 0,001 \\
\hline Metode-Motivasi & 0,580 & 0,933 & 0,859 \\
\hline Sikap-Motivasi & 0,304 & 0,006 & 0,007 \\
\hline Metode-Sikap-Motivasi & 0,030 & 0,239 & 0,067 \\
\hline
\end{tabular}

Hasil analisis Tabel 1 dapat disimpulkan bahwa:

1. Pengaruh pembelajaran metode inkuiri terbimbing dan metode inkuiri bebas termodifikasi terhadap prestasi belajar siswa.

Berdasarkan Tabel 1 nilai pada probabilitas nilai pengetahuan $p$-value $=$ 0,011 , probabilitas aspek sikap $p$-value $=$ 0,007 probabilitas aspek keterampilan $p$ value $=0,001$. Hasil uji menunjukkan pada nilai pengetahuan, sikap dan keterampilan adalah $p$-value $<0,05$, maka dapat diiferensikan bahwa ada perbedaan pengaruh pendekatan konstruktivisme menggunakan metode inkuiri bebas termodifikasi dan metode inkuiri terbimbing terhadap nilai pengetahuan, sikap, dan keterampilan.

Hal ini menunjukkan bahwa siswa menyukai metode yang disampaikan dan dapat dikatakan bahwa penerapan metode inkuiri terbimbing berhasil. Sesuai dengan penelitian Abdi (2014), pembelajaran melalui pembelajaran berbasis inkuiri dicapai skor yang lebih tinggi daripada yang yang diinstruksikan melalui metode tradisional. Pada pelaksanaannya, guru memberikan suatu masalah berdasarkan fenomena riil yang sering dijumpai oleh siswa pada pokok bahasan Impuls, Momentum, dan Tumbukan. Guru menuntun penyusunan hipotesis, merancang percobaan, melakukan percobaan, mengumpulkan dan menganalisis data, hingga penarikan kesimpulan dengan menggunakan bantuan pertanyaan. Dalam hal ini siswa dituntut aktif selama proses pembelajaran. Guru kelas mempersiapkan lingkungan belajar di mana siswa akan aktif sesuai dengan karakteristiknya dan kemudian menyajikan lingkungan yang sesuai dengan karakteristik materi.

Pada pembelajaran fisika yang menggunakan metode inkuiri terbimbing dan inkuiri bebas termodifikasi dengan pendekatan konstruktivisme selama proses pembelajaran memberikan berpengaruh terhadap prestasi belajar siswa. Menurut Gupta (2007) memperlihatkan bahwa konstruktivisme dapat meningkatkan prestasi belajar siswa. Penelitian ini juga memperlihatkan bahwa konstruktivisme memberikan hasil yang lebih baik dibandingkan dengan kolaboratif berpasangan yang diajarkan dengan instruksi guru. Pendekatan konstruktivisme yang penerapannya menggunakan metode inkuiri menuntut siswa aktif secara individual, kreatif, dan inovatif. Adanya beberapa siswa yang kurang fokus selama proses pembelajaran, antusias dalam melakukan percobaan namun masih kesulitan dalam menyimpulan data menjadi kendala.

2. Pengaruh motivasi berprestasi tinggi dan motivasi berprestasi rendah terhadap prestasi belajar siswa.

Berdasarkan Tabel 1 nilai probabilitas aspek pengetahuan $p$-value= 0,000 , probabilitas aspek sikap $p$ - 
value $=0,000$ dan probabilitas aspek keterampilan $p$-value $=0,000$. Hasil uji menunjukkan pada prestasi pengetahuan, sikap dan keterampilan adalah p-value < 0,05 , maka dapat diiferensikan bahwa ada perbedaan prestasi belajar (pengetahuan, sikap, keterampilan) bagi peserta didik yang memiliki sikap ilmiah tinggi dan rendah. Sikap ilmiah yang ditinjau dalam penelitian ini berdasarkan hasil angket yang diberikan pada siswa. Rerata nilai prestasi belajar pengetahuan, sikap, dan keterampilan peserta didik yang memiliki sikap ilmiah tinggi lebih baik daripada peserta didik dengan sikap ilmiah rendah. Sikap merupakan suatu kecenderungan untuk bertindak secara suka atau tidak suka terhadap suatu objek (Depdiknas, 2008: 4). Perubahan sikap dapat diamati dalam proses pembelajaran, tujuan yang ingin dicapai, keteguhan, dan konsistensi terhadap sesuatu. Fisika merupakan ilmu yang menuntut aplikasi riil dilapangan yang bekerja secara ilmiah, kreatif, dan inovatif. Aplikasi riil dilapangan siswa mencakup pengembangan keterampilan praktis, mengamati suatu masalah, melakukan investigasi, mengambil data, dan menyimpulkan. Investigasi memberikan kesempatan utama bagi siswa untuk memperluas pemahaman siswa tentang sains. Sehingga guru harus benar-benar menciptakan suasana belajar mendukung tercapainya proses ilmiah.

3. Pengaruh sikap ilmiah tinggi dan sikap ilmiah rendah terhadap prestasi belajar siswa.

Berdasarkan Tabel 1 nilai probabilitas aspek pengetahuan $p$ value $=0,006$, probabilitas aspek sikap $p$ value $=0,041$, dan probabilitas aspek keterampilan $p$-value $=0,001$. Hasil uji menunjukkan pada prestasi pengetahuan, sikap dan keterampilan adalah p-value < 0,05 , maka dapat diiferensikan bahwa ada perbedaan prestasi belajar (pengetahuan, sikap, keterampilan) bagi peserta didik yang memiliki motivasi berprestasi tinggi dan rendah. Siswa antusias dalam mengikuti proses pembelajaran yang diberikan.

Hal ini mengindikasikan motivasi berprestasi tinggi cenderung dapat meningkatkan prestasi belajar siswa. Penelitian Lee (2010) menyatakan bahwa motivasi belajar memberikan dampak yang positif untuk meningkatkan prestasi belajar siswa. Pola pembelajaran yang berkualitas menuntut guru memperhatikan kondisi psikis siswa benar-benar siap saat proses pembelajaran. Dalam proses pembelajaran, guru mendampingi siswa, mengamati tingkat laku, dan mengamatinya dalam interaksi dengan kelompok. Dengan sistem pendampingan siswa akan lebih mudah diamati sehingga setiap masalah yang dihadapi segera terselesaikan.

4. Interaksi pengaruh antara metode inkuiri terbimbing dan inkuiri bebas termodifikiasi dengan motivasi berprestasi tinggi dan rendah terhadap hasil prestasi siswa.

Berdasarkan Tabel 1 nilai probabilitas aspek pengetahuan $p$-value $=$ 0,580 , probabilitas aspek sikap $p$-value $=$ 0,933 dan probabilitas aspek keterampilan $p$-value $=0,859$. Hasil menunjukkan pada prestasi pengetahuan, sikap dan keterampilan adalah p-vlaue $>0,05$; maka H0 diterima, berarti interaksi antara pendekatan konstruktivisme menggunakan metode inkuiri bebas termodifikasi dan metode inkuiri terbimbing dengan sikap ilmiah memberikan pengaruh yang sama terhadap nilai pengetahuan, sikap dan keterampilan. Namun secara keseluruhan menunjukkan distribusi prestasi belajar pengetahuan, sikap, dan keterampilan peserta didik yang memiliki sikap ilmiah tinggi secara keseluruhan memiliki hasil yang lebih baik jika dibandingkan dengan peserta didik dengan sikap ilmiah rendah baik pada kelas yang diberi pembelajaran dengan metode inkuiri bebas termodifikasi dan inkuiri terbimbing. Sesuai penelitian Fakhruddin, Eprina, dan Syahril (2010) menyatakan bahwa selama proses pembelajaran sikap ilmiah siswa meningkat 
tiap pertemuan. Dengan demikian, secara keseluruhan sikap ilmiah siswa dapat dilatihkan dengan penggunaan media yang tentunya disesuaikan dengan karakteristik mteri yang disampaikan.

Sikap ilmiah merupakan sikap perilaku peserta didik yang harus dimiliki seperti layaknya ilmuwan. Dalam pembelajaran sikap ilmiah siswa sangat diperlukan sikap rasa ingin tahu, bekerja sama secara terbuka, bekerja keras, bertanggung jawab, kepedulian, kedisiplinan dan kejujuran. Dengan sikap ilmiah tersebut pembelajaran akan berjalan dengan baik, sehingga mencapai tujuan pembelajaran dan hasil belajar yang diinginkan, dimana siswa diharapkan mampu aktif dan kreatif dalam pembelajaran. Sikap ilmiah siswa dapat ditumbuh kembangkan melalui kegiatan percobaan dalam proses pembelajaran (Fakhruddin, et al., 2010: 18-19).

5. Interaksi pengaruh antara metode inkuiri terbimbing dan inkuiri bebas termodifikiasi dengan sikap ilmiah tinggi dan rendah terhadap prestasi belajar siswa.

Berdasarkan Tabel 1 nilai pada probabilitas aspek pengetahuan $p$-value $=$ 0,304 , aspek sikap $p$-value $=0,006$ dan probabilitas aspek keterampilan $p$ value $=0,007$. Hasil uji pada prestasi pengetahuan, adalah $p$-value $>0,05$; maka Ho diterima, berarti interaksi antara pendekatan konstruktivisme menggunakan metode inkuiri bebas termodifikasi dan metode inkuiri terbimbing dengan motivasi berprestasi memberikan pengaruh yang sama terhadap prestasi pengetahuan. Sedangkan pada sikap dan keterampilan menunjukkan nilai $p$-value $<0,05$; maka Ho ditolak, berarti interaksi pendekatan konstruktivisme menggunakan metode inkuiri bebas termodifikasi dan metode inkuiri terbimbing dengan motivasi berprestasi memberikan pengaruh yang signifikan terhadap nilai sikap dan keterampilan. Menurut Sardiman (2001: 81) motivasi di dalam diri seseorang memiliki ciri-ciri yaitu: tekun menghadapi tugas, ulet menghadapi kesulitan, tidak memerlukan dorongan dari dari luar untuk berprestasi sebaik mungkin, menunjukkan minat terhadap bermacam-macam masalah, lebih senang bekerja mandiri, cepat bosan dengan tugas-tugas rutin, dapat mempertahankan pendapatnya, tidak mudah melepas hal yang diyakini, senang mencari dan memecahkan masalah. Tidak adanya interaksi pada aspek pengetahuan terjadi karena siswa secara umum cocok dengan metode pembelajaran yang disampaikan sehingga semua semua komponen ciri-ciri motivasi menurut Sardiman (2001) sudah melekat pada diri siswa. Siswa menunjukkan antusiasme yang tinggi untuk mengikuti proses pembelajaran dari awal hingga akhir.

6. Interaksi pengaruh antara sikap ilmiah tinggi dan rendah dengan motivasi berprestasi tinggi dan rendah terhadap prestasi belajar siswa.

Berdasarkan Tabel 1 nilai pada probabilitas aspek pengetahuan $p$-value $=$ 0,030 , probabilitas aspek sikap $p$ value $=0,239$ dan probabilitas aspek keterampilan $p$-value $=0,067$. Hasil uji menunjukkan pada prestasi sikap dan keterampilan adalah $p$-value > 0,05; maka Ho diterima, berarti interaksi antara sikap ilmiah dengan motivasi berprestasi memberikan pengaruh yang sama terhadap nilai sikap dan keterampilan. Pada pengetahuan menunjukkan nilai $p$ value $<0,05$; maka Ho ditolak, berarti interaksi antara sikap ilmiah dengan motivasi berprestasi memberikan pengaruh yang signifikan terhadap nilai pengetahuan. Data distribusi frekuensi juga menunjukkan secara keseluruhan rerata nilai prestasi belajar (pengetahuan, sikap, dan keterampilan) peserta didik yang memiliki sikap ilmiah tinggi dan rendah kemudian dihubungkan dengan motivasi berprestasi tinggi dan rendah memiliki perbedaan yang signifikan.

$\begin{array}{llr}\text { Motivasi berprestasi dan } & \text { sikap } \\ \text { ilmiah merupakan komponen } & \text { yang } \\ \text { mempengaruhi hasil belajar } & \text { siswa. }\end{array}$


Penelitian Levy (2008) menyatakan bahwa prestasi belajar siswa meningkat setelah guru berkomitmen menyeimbangkan motivasi ekstrinsik dan instrinsik sebagai salah satu komponen strategi belajar. Pertimbangan memotivasi belajar siswa tidak hanya menjadi tanggungjawab guru namun semua staf akademik memainkan peran yang sama. Konsep motivasi dimasukkan dalam kurikulum pembelajaran. Sehingga sinkronisasi anatar guru, siswa, kurikulum, dan staf akademik akan terwujud. Sedangkan penelitian Ataha1 dan Ogumogu (2013) menyatakan bahwa kombinasi dan pemetaan porsi yang tepat antara kegiatan eksperimen dan teori saat proses pembelajaran berlangsung sangat membantu meningkatkan sikap ilmiah siswa. Siswa akan dapat mengkombinasikan antara teori yang diperoleh dan mengaplikasikannya saat melakukan eksperimen. Selain itu, kegiatan diskusi ilmiah dan merancang percobaan akan mendorong siswa untuk berpikir ilmiah sehingga secara natural sikap ilmiah akan terbentuk. Kedua faktor ini, baik motivasi berprestasi dan sikap ilmiah merupakan dua hal yang berbeda. Pada saat pembelajaran, ada siswa yang memiliki motivasi belajar tinggi, namun memiliki sikap ilmiah yang rendah karena belum menguasai konsep materi secara utuh. Keduanya berbeda, namun berjalan berdampingan yang tentunya sangat berpengaruh pada hasil belajar.

7. Interaksi pengaruh antara pembelajaran konstruktivisme dengan menggunakan metode inkuiri terbimbing dan metode inkuiri bebas termodifikasi dengan motivasi berprestasi dan sikap ilmiah terhadap prestasi belajar siswa.

Berdasarkan Tabel 1 nilai pada probabilitas aspek pengetahuan $p$-value $=$ 0,630 , probabilitas aspek sikap $p$-value $=$ 0,054 dan probabilitas aspek keterampilan $p$-value $=0,511$. Hasil uji menunjukkan pada prestasi pengetahuan, sikap dan keterampilan adalah $p$-value $>0,05$; maka Ho diterima, berarti interaksi antara pendekatan konstruktivisme menggunakan metode inkuiri bebas termodifikasi dan ikuiri terbimbing, sikap ilmiah, dan motivasi berprestasi memberikan pengaruh yang sama terhadap nilai pengetahuan, sikap, dan keterampilan.

Pada penelitian ini, pendekatan yang digunakan adalah konstruktivisme. proses pembelajaran yang diawali konflik kognitif, yang pada akhirnya pengetahuan akan dibangun sendiri oleh siswa melalui pengalaman dan hasil interaksi dengan lingkungannya. Model pembelajaran konstruktivisme menekankan pada pengembangan kemampuan, keterampilan (hand-on), dan pemikiran siswa (mind-on). Saat mempelajari ilmu fisika, siswa dapat mengamati, mengukur, mengumpulkan data, menganalisa data, dan menyimpulkan. Metode ilmiah yang sangat jelas menunjukkan proses abstraksi terhadap kejadian kongkrit, tepat digunakan untuk mempelajari fisika. Pembelajaran sesuai dengan metode ilmiah menuntut siswa untuk aktif, bukan menerima pengajaran dari guru secara pasif. Sesuai penelitian Khalid dan Azeem (2012) menyatakan bahwa pendekatan konstruktivisme layak dilakukan dalam proses pembelajaran karena melibatkan siswa dalam kegiatan inovatif dan kreatif. Penelitian ini membandingkan pembelajaran konvensional dalam arti tanpa pendekatan tertentu dengan pendekatan konstruktivisme. Perbedaan signifikan diperoleh berdasarkan hasil postes pada kelompok kontrol dan kelompok eksperimen. Kelompok eksperimen dengan pendekatan konstruktivisme memiliki rerata nilai yang lebih baik dari kelompok kontrol dengan pendekatan tradisional.

\section{Kesimpulan dan Rekomendasi}

Berdasarkan hasil analisis dan pengujian hipotesis yang telah dipaparkan, dapat disimpulkan 1). Ada perbedaan pengaruh pendekatan konstruktivisme menggunakan metode inkuiri bebas termodifikasi dan metode inkuiri 
terbimbing terhadap nilai pengetahuan, sikap dan keterampilan. 2) Ada perbedaan pengaruh antara sikap ilmiah tinggi dan rendah terhadap nilai pengethuan, sikap dan keterampilan. 3) Ada perbedaan pengaruh antara motivasi berprestasi tinggi dan rendah terhadap nilai pengetahuan, sikap dan keterampilan. 4) Tidak ada interaksi pengaruh antara pendekatan konstruktivisme menggunakan metode inkuiri bebas termodifikasi dan metode inkuiri terbimbing dengan sikap ilmiah terhadap nilai pengetahuan, sikap dan keterampilan. 5) Tidak ada interaksi pengaruh antara pembelajaran dengan pendekatan konstruktivisme menggunakan metode inkuiri bebas termodifikasi dan metode inkuiri terbimbing dengan motivasi berprestasi terhadap prestasi pengetahuan siswa. 6) Tidak ada interaksi pengaruh antara sikap ilmiah dengan motivasi berprestasi terhadap prestasi sikap dan keterampilan. 7) Tidak ada interaksi pengaruh antara pembelajaran dengan pendekatan konstruktivisme menggunakan metode inkuiri bebas termodifikasi dan ikuiri terbimbing, sikap ilmiah, dan motivasi berprestasi terhadap prestasi aspek pengetahuan, sikap, dan keterampilan. Berdasarkan simpulan dan implikasi hasil penelitian, sebagai perbaikan dan peningkatan dalam pembelajaran fisika saran dari peneliti adalah: 1) Metode belajar inkuiri bebas termodifikasi dan inkuiri terbimbing yang akan digunakan peneliti dalam pembelajaran dapat digunakan terlebih dahulu agar diketahui kelebihan dan kekurangan serta dapat lebih mengetahui kesiapan peserta didik dalam penyampaian materi dengan metode yang digunakan. 2) Mengetahui secara mendalam faktor internal pada peserta didik, seperti sikap ilmiah, dan peneliti tidak hanya mengkategorikannya dalam skala tinggi dan rendah tetapi juga mengelompokkan dalam kategori sedang sehingga peneliti bisa benar-benar mengetahui kemampuan peserta didik.

\section{Daftar Pustaka}

Abdi, A. (2014). The Effect of Inquiry-based Learning Method on Students Academic Achievement in Science Course. Universal Journal of Educational Research, 2 (1), 37-41.

Adnyani, N.W., Sadia, I.W., \& Natajaya, I. N. (2013). Pengaruh Strategi Pembelajaran Konflik Kognitif Terhadap Penurunan Miskonsepsi Fisika Ditinjau dari Gaya Kognitif Siswa Kelas X di SMA Negeri 1 Bebandem. e-Journal Program Pascasarjana Universitas Pendidikan Ganesha.4 (1).

Ataha1, U. C. \& Ogumogu, A. E. (2013). An Investigation Of The cientific Attitude Among Science Students In Senior Secondary Schools In Edo South Senatorial District, Edo State. Journal of Education and Practice, 4(11), 1216.

Depdiknas. (2008). Kurikulum Tingkat Satuan Pendidikan. Jakarta: Dikmenum. Depdiknas.

Fakhruddin, Eprina, A., \& Syahril. (2010). Sikap Ilmiah Siswa Dalam Pembelajaran Fisika Dengan Penggunaan Media Komputer Melalui Model Kooperatif Tipe STAD Pada Siswa Kelas X3 SMA Negeri I Bangkinang Barat. Jurnal Geliga Sains. 4 (1), 18-22.

Gupta, A. (2008). "Constructivism and Peer Collaboration in Elementary Mathematics Education: The Connection to Epistemology". Eurasia Journal of Mathematics, Science \& Technology Education, 4(4), 381-386.

Khalid, A. \& Azeem, M.,(2012). Constructivist Vs Traditional: Effective Instructional Approach in Teacher Education. International Journal of Humanities and Social Science, 2 (5), 170-177.

Lee, I-C. (2010). The Effect of Learning Motivation, Total Quality Teaching and Peer-Assisted Learning on Study Achievement: Empirical Analysis from Vocational Universities or Colleges' students in Taiwan. The Journal of 
Human Resource and Adult Learning, 6 (2), 56-73.

Levy, S. (2008). Student Motivation: Premise, Eective Practice and Policy. Australian Journal of Teacher Education, 33(5), 14-28.

Sardiman, A. (2001). Interaksi dan Motivasi Belajar Mengajar. Jakarta: PT Raja. Grafindo Persada.

Suparno, P. (2007). Metodologi Pembelajaran Fisika Konstruktivistik \& Menyenangkan. Yogyakarta:

Universitas Sanata Darma. 